Old Style 



\title{
Old Style
}

Unoriginality and Its Uses in Nineteenth-Century

U.S. Literature

\section{Claudia Stokes}

\author{
$\overline{\text { PENN }}$ \\ UNIVERSITY OF PENNSYLVANIA PRESS \\ PHIL A DE L P H I A
}


Copyright $\odot 2022$ University of Pennsylvania Press

All rights reserved.

Except for brief quotations used for purposes of review or scholarly citation, none of this book may be reproduced in any form by any means without written permission from the publisher.

\author{
Published by \\ University of Pennsylvania Press \\ Philadelphia, Pennsylvania 19104-4112 \\ www.upenn.edu/pennpress \\ Printed in the United States of America \\ on acid-free paper \\ $\begin{array}{llllllllll}10 & 9 & 8 & 7 & 6 & 5 & 4 & 3 & 2 & 1\end{array}$
}

Library of Congress Cataloging-in-Publication Data

Names: Stokes, Claudia, author.

Title: Old style : unoriginality and its uses in nineteenth-century U.S. literature /

Claudia Stokes.

Description: 1st edition. | Philadelphia : University of Pennsylvania Press, [2021] |

Includes bibliographical references and index.

Identifiers: LCCN 2021005728 | ISBN 9780812253535 (hardcover)

Subjects: LCSH: American literature-19th century-History and criticism. |

Originality in literature. | Imitation in literature. | Influence (Literary, artistic, etc.) |

Conservatism in literature. | Conservatism and literature-United States-

History-19th century.

Classification: LCC PS201 .S76 2021 | DDC 810.9/003-dc23

LC record available at https://lccn.loc.gov/2021005728 
For Eleanor and Simon 
